\title{
Aerobic expression of the cyf gene encoding cytochrome c-553 from Desulfovibrio vulgaris Hildenborough in Escherichia coli
}

\author{
W. Brent R. Pollock† and Gerrit Voordouw \\ Author for correspondence: Gerrit Voordouw. Tel: +1 403220 6388. Fax : +1 4032899311. \\ e-mail: voordouw@acs.ucalgary.ca
}

Division of Biochemistry, Department of Biological Sciences, The University of Calgary, Alberta, Canada T2N 1 N4

\begin{abstract}
Monohaem cytochrome c-553 from Desulfovibrio vulgaris Hildenborough is encoded by the cyf gene which could be expressed in Escherichia coli to yield the periplasmic holoform of cytochrome c-553. Covalent haem attachment was shown by labelling with 5 -amino $\left[4-{ }^{14} \mathrm{C}\right]$ laevulinic acid, the immediate precursor for haem biosynthesis. Visible-absorption spectroscopy demonstrated that the haem environment in the recombinant protein did not differ from the native protein. Optimal expression was obtained under aerobic conditions.

Furthermore, efficient insertion of haem into a cytochrome c-553- $\beta$-lactamase fusion protein could be demonstrated. We suggest that the varying success in heterologous expression of c-type cytochromes in $E$. coli may arise as a result of differences in the physical properties of the apoproteins.
\end{abstract}

Keywords: cytochrome c-553, cyf gene, Desulfovibrio vulgaris Hildenborough, Escherichia coli, heterologous expression

\section{INTRODUCTION}

All c-type cytochromes have thioether bonds which covalently link haem to the polypeptide. These bonds are between the vinyl groups of the haem and the cysteinyl groups in the canonical polypeptide sequence $\mathrm{CX}_{\mathrm{a}} \mathrm{X}_{\mathrm{b}} \mathrm{CH}$, wherein $\mathrm{X}_{\mathrm{a}}$ and $\mathrm{X}_{\mathrm{b}}$ are variable amino acids. It has been demonstrated (Dumont $e t$ al., 1987; Drygas et al., 1989) that thioether bond formation in mitochondrial cytochrome $c$ requires a nuclear encoded protein which has been named cytochrome $c$ haem lyase. Peculiarly, the existence of a similar protein in prokaryotes active in covalent haem insertion remains to be proven. Mutants have been isolated which are deficient in $c$-type cytochrome biosynthesis (Biel \& Biel, 1990; Page \& Ferguson, 1990; Ramseier et al., 1991; Beckman et al., 1992) but sequence analysis of the mutated loci has indicated that the encoded polypeptides may facilitate transport of $c$ type cytochromes (Ramseier et al., 1991).

\footnotetext{
†Present address: Department of Biochemistry, University of British Columbia, Vancouver, Canada.

Abbreviations: Amp, ampicillin; Bla, $\beta$-lactamase; bla, structural gene encoding Bla; Cyf, cytochrome c-553; cyf, structural gene encoding Cyf; IPTG: isopropylindolyl $\beta$-D-thiogalactopyranoside; $\mathrm{Km}$, kanamycin; TMAO: trimethylamine- $N$-oxide; TMBZ, 3,3',5,5'-tetramethylbenzidine; $T Y$, tryptone-yeast extract medium; X-P, 5-bromo-4-chloro-3-indolyl phosphate.
}

We have previously reported that Escherichia coli cannot synthesize the holoform of the tetrahaemic cytochrome $c_{3}$ from Desulfovibrio vulgaris Hildenborough (Pollock $e t$ al., 1989), although Rhodobacter sphaeroides is able to synthesize low levels of the holoform (Cannac et al., 1991). D. vulgaris has at least two other $c$-type cytochromes: cytochrome $c$ 553 , a $9 \mathrm{kDa}$, monohaemic cytochrome, and Hmc, a $70 \mathrm{kDa}$ hexadecahaemic cytochrome (Pollock et al., 1991). Several attempts at expressing foreign, monohaemic ctype cytochromes in E. coli have been made with an as yet unexplained varying degree of success (McEwan et al., 1989; Self et al., 1990; von Wachenfeldt \& Hederstedt, 1990b; Grisshammer et al., 1991; Sanbongi et al., 1991; Ubbink et al., 1992). Therefore, it is of interest to determine whether E. coli can synthesize the holocytochrome $c-553$, which could be simpler than the tetrahaem cytochrome $c_{3}$.

The structural gene for cytochrome $c-553$, referred to from here on as $c y f$, has been cloned and sequenced (van Rooijen et al., 1989). The cyf gene encodes a polypeptide of 103 residues (pro-Cyf). An N-terminal signal peptide of 24 residues directs the export of this polypeptide to the periplasm; cleavage of the signal peptide and haem insertion renders the mature holoprotein (Cyf). The structure of Cyf is known from X-ray crystallographic data (Nakagawa et al., 1990) and 2D-NMR (Marion \& Guerlesquin, 1992). Herein we report the heterologous expression of Cyf in E. coli. 
Table 1. Bacterial strains and plasmids

\begin{tabular}{|c|c|}
\hline Strain or plasmid & Genotype, comments and reference \\
\hline $\begin{array}{l}\text { D. vulgaris } \\
\text { Hildenborough }\end{array}$ & $\begin{array}{l}\text { NCIMB 8303; isolated from clay soil near Hildenborough, Kent, UK } \\
\text { (Postgate, 1984); source of the cyf gene encoding cytochrome } c-553 \text { (van } \\
\text { Rooijen } e \text { t al., 1989) }\end{array}$ \\
\hline D. desulfuricans $\mathrm{G} 200$ & $\begin{array}{l}\text { Spontaneous } \mathrm{Nal}^{r} \text { derivative of D. desulfuricans G100A (Weimar et al., } \\
\text { 1988) }\end{array}$ \\
\hline E. coli TG2 & $\begin{array}{l}\Delta(\text { lac-pro }) \text { supE thi bsdM bsd } \mathrm{R} \operatorname{rec} A\left[\mathrm{~F}^{\prime} \operatorname{traD} 36 \text { pro } A B^{+} \text {lac } Z \Delta \mathrm{M} 15 I^{\circ}\right] \\
\text { from T. J. Gibson* }\end{array}$ \\
\hline pKUL6 & $\begin{array}{l}\text { Contains the levansucrase signal peptide gene fused in-frame to the gene } \\
\text { of mature } \beta \text {-lactamase (Nivière } \text { et al., 1992) }\end{array}$ \\
\hline pKUL7 & $\begin{array}{l}\text { Derivative of plasmid pKUL6 with the signal peptide gene deleted } \\
\text { (Nivière } \text { et al., 1992) }\end{array}$ \\
\hline pUC9 & $A_{m p}^{r}$ (Vieira \& Messing, 1982) \\
\hline pUC13 & Amp $^{r}$ (Messing, 1983) \\
\hline pUC18 & Amp $^{r}$ (Yanisch-Perron et al., 1985) \\
\hline pJRD215 & $\begin{array}{l}\text { IncQ group, broad-host-range cloning vector; } \mathrm{Km}^{\mathrm{r}} \mathrm{Sm}^{\mathrm{r}} \text { (Davison et al., } \\
\text { 1987)† }\end{array}$ \\
\hline $\mathrm{pC} 41$ & Contains the cyf gene on a 736 bp fragment in pUC9 \\
\hline pJRC41 & Contains the 736 bp EcoRI-HindIII insert of pC41 in pJRD215† \\
\hline pDUL44 & $\begin{array}{l}\text { Contains the cyf gene fused in-frame to the gene of mature } \beta \text {-lactamase in } \\
\text { pJRD215; this work } \dagger\end{array}$ \\
\hline pDUL45 & $\begin{array}{l}\text { As pDUL } 44 \text { but with the } 3^{\prime} \text { end of the } \beta \text {-lactamase gene deleted; this } \\
\text { work } \dagger\end{array}$ \\
\hline $\begin{array}{l}\text { pVIP18, pPP18, } \\
\text { pKUL43, pKUL44 } \\
\text { and pUC45 }\end{array}$ & Intermediates in the construction of pDUL44 and pDUL45 \\
\hline
\end{tabular}

* Constructed from E. coli JM101 by T. J. Gibson and M. D. Biggin at the Laboratory of Molecular Biology, MRC Centre, Cambridge, UK.

† The broad-host-range properties of this plasmid are not important for the present study, since expression was only studied in E. coli. Transformants were selected by their kanamycin resistance.

\section{METHODS}

Biochemical reagents. All enzymes were obtained from either Pharmacia or Boehringer Mannheim. The radiochemical 5amino $\left[4-{ }^{14} \mathrm{C}\right]$ laevulinic acid hydrochloride $\left[56 \mathrm{mCi} \mathrm{mmol}^{-1}\right.$; diluted with sterile distilled water to $83.3 \mu \mathrm{Ci} \mathrm{ml}^{-1}$ (3.082 MBq $\left.\mathrm{ml}^{-1}\right)$ ] was purchased from Amersham. Nitrocellulose was from Schleicher \& Schuell. Reagents for colour development in Western blotting, alkaline-phosphatase-conjugated goat antirabbit immunoglobulin $G$, nitroblue tetrazolium, and 5-bromo4-chloro-3-indolyl phosphate (X-P) substrates, were purchased from Promega. All other reagent-grade chemicals were from either Sigma or Fisher.

Growth of bacteria. Liquid cultures of E. coli transformants were grown at $37^{\circ} \mathrm{C}$, either aerobically with shaking at 250 r.p.m., or anaerobically without agitation. E. coli TG2 was kept on M9 minimal glucose plates and transformants were grown on tryptone-yeast extract (TY) agar plates to which the appropriate antibiotic $\left(100 \mu \mathrm{g} \mathrm{ml}^{-1}\right.$ for ampicillin and $10 \mu \mathrm{g} \mathrm{ml}^{-1}$ for kanamycin), IPTG $\left(16 \mu \mathrm{g} \mathrm{m}^{-1}\right)$ and X-Gal $\left(32 \mu \mathrm{g} \mathrm{ml}^{-1}\right)$ were added when required. Liquid cultures were in $5.0 \mathrm{ml}$ of TY medium (Voordouw et al., 1989) with the same concentration of antibiotics when required. M9 minimal medium (Miller, 1972) was used for radiolabelling studies. Anaerobic cultures were in TMAO medium (Bragg \& Hackett, 1983). Bottles (100 ml) were filled with TMAO medium, flushed under nitrogen, sealed and autoclaved.
Strains, vectors and plasmids. The bacterial strains, vectors and plasmids used are described in Table 1. DNA manipulations were carried out essentially according to Sambrook et al. (1989). Plasmid pJRC41 was obtained by transferring the $736 \mathrm{bp}$ HindIII-EcoRI insert from an M13 clone (van Rooijen et al., 1989) to plasmid pJRD215 (Fig. 1). In addition to pJRC41, two plasmids encoding fusions of Cyf and $\beta$-lactamase, pDUL44 and pDUL45, were constructed. The presence of plasmids pJRD215, pJRC41, pDUL44 or pDUL45 in E. coli was indicated by the kanamycin resistance of the resulting transformants.

Plasmid pDUL44 was derived from plasmid pKUL44 which was constructed as follows. The $736 \mathrm{bp}$ insert of pC41 was first digested with MaeI (Fig. 1: a MaeI site is situated exactly at the 3 -end of the cyf gene) then blunt-ended with mung-bean nuclease. Next it was digested with PstI and finally ligated with pUC18 digested with Pst and SmaI. Plasmid pVIP18, isolated from the ligation mixture, was digested with $K p n \mathrm{I}$ and EcoRI, blunt-ended with T4 DNA polymerase in the presence of dNTPs, and self-ligated to give plasmid pPP18. Two fragments (a $2.4 \mathrm{~kb} \mathrm{BamHI-EcoRI} \mathrm{fragment} \mathrm{and} \mathrm{a} 1.8 \mathrm{~kb}$ EcoRI fragment containing the truncated bla gene) were isolated from a digest of pKUL7 by agarose gel electrophoresis. Ligation of the $c y f$ containing, $0.4 \mathrm{~kb} \mathrm{BamHI-EcoRI} \mathrm{fragment} \mathrm{of} \mathrm{pPP1} 8$ and the $2.4 \mathrm{~kb} B a m \mathrm{HI}-E c o \mathrm{RI}$ fragment of pKUL7 gave pKUL43. Insertion of the $1.8 \mathrm{~kb}$ EcoRI fragment of pKUL7 in the correct orientation gave pKUL44. The $2 \cdot 2 \mathrm{~kb}$ insert of pKUL44 was transferred to vector pJRD215 by digestion with HindIII and 
$\mathbf{A}$

pJRC41

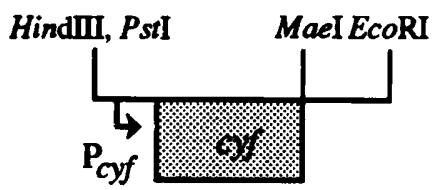

\section{$1000 \mathrm{bp}$}
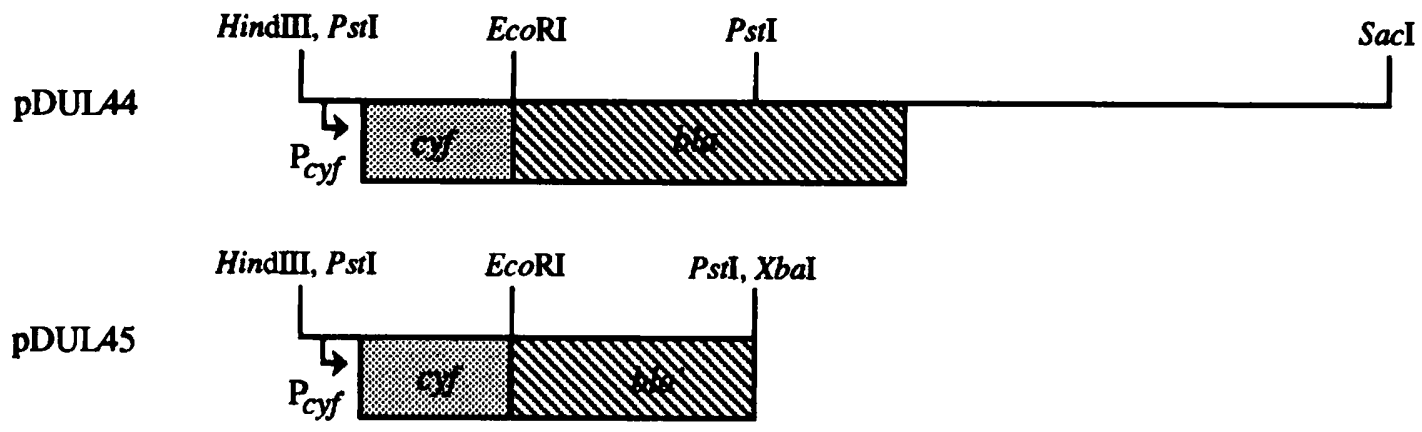

B
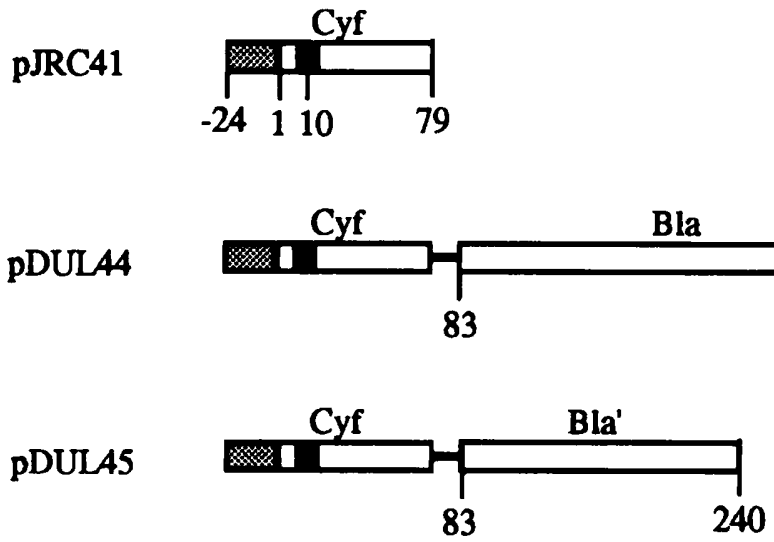

Fig. 1. A, Inserts of plasmids pJRC41, pDUL44 or pDUL45 containing the cyf gene or a cyf-bla fusion. Only relevant restriction enzyme sites have been illustrated. The putative cyf promoter (Pollock, 1992) and direction of transcription are indicated by arrows. The bla gene of pDUL45 is truncated at the $3^{\prime}$ end (b/a'). B, Features of proteins encoded by the plasmids in (A). All have the Cyf signal peptide (residues -24 to -1 , shaded) followed by the complete Cyf sequence (residues 1 to 79). The haem binding site (Cys-lle-Gly-Cys-His) starts at residue 10 (black). Residues 80 to 82 are a pUC vector derived linker peptide. Residues 83 to 344 or 83 to 240 are the Bla domain and the truncated Bla domain (Bla').

SacI and ligation to give pDUL44 (Fig. 1A), which encodes the Cyf-Bla fusion protein indicated in Fig. 1 (B).

For the construction of plasmid pDUL45 the 900 bp PstI fragment was isolated from pKUL44 and ligated into the vector pUC13. Plasmid pUC45 with the desired orientation of the insert was selected by BamHI digestion. The 900 bp HindIII$\mathrm{Xbal}$ fragment was isolated from $\mathrm{pUC} 45$ and ligated into vector pJRD215 to give pDUL45 (Fig. 1A), which encodes a Cyf-Bla fusion protein that is truncated at the $\mathrm{C}$-terminus (Fig. 1B). Both $c y f-b l a$ fusions are expected to encode proteins in which an $\mathrm{N}$ terminal Cyf domain is linked to a C-terminal Bla domain through three bridging residues (-G-I-P-) encoded by DNA from the pUC vector. In both constructions the Bla domain starts at residue 2 of mature $\beta$-lactamase.

Labelling, SDSPAGE, blotting and visible spectroscopy.
Periplasmic and membrane/cytoplasmic fractions of E. coli transformants were prepared as previously described (Pollock $e t$ al., 1989). For in vivo labelling of E. coli TG2 transformants a single colony was used to inoculate $5.0 \mathrm{ml}$ of $\mathrm{M} 9$ medium containing kanamycin and $1.6 \mu \mathrm{Ci}(59.2 \mathrm{kBq})$ of 5 -amino[4${ }^{14} \mathrm{C}$ laevulinic acid. After overnight growth, the cells were collected and periplasmic and membrane/cytoplasmic fractions were prepared. The periplasmic fractions were analysed by SDS-PAGE.

SDS-PAGE was done essentially according to Laemmli (1970), as detailed by Pollock et al. (1989) using gradient gels of $3 \%$ $(\mathrm{w} / \mathrm{v})$ bisacrylamide and $7 \%(\mathrm{w} / \mathrm{v})$ acrylamide to $5 \%(\mathrm{w} / \mathrm{v})$ bisacrylamide and $20 \%(\mathrm{w} / \mathrm{v})$ acrylamide. Following SDSPAGE, proteins were transferred electrophoretically to nitrocellulose as detailed by Pollock et al. (1989) except that the transfer buffer contained $0 \cdot 1 \%(\mathrm{w} / \mathrm{v})$ SDS. The protein blots 
were incubated either with polyclonal antisera raised against purified $D$. vulgaris Hildenborough holocytochrome $c-553$ or with purified polyclonal antisera raised against $E$. coli $\beta$ lactamase (Nivière et al., 1992) as the primary antibody. An alkaline-phosphatase-conjugated goat anti-rabbit IgG was used as the secondary antibody and the blot was immunostained with nitroblue tetrazolium and X-P. Blots to which ${ }^{14} \mathrm{C}$-labelled samples were transferred were autoradiographed directly.

Visible spectroscopy was carried out with a Shimadzu UVVisible recording spectrophotometer (model UV-265), using quartz cells with a pathlength of $1.0 \mathrm{~cm}$ and sample volumes of $1.0 \mathrm{ml}$. Post-electrophoretic porphyrin-c fluorescence analysis was carried out as previously described (Pollock et al., 1989). Staining for haem peroxidase activity using TMBZ as a substrate was done according to Thomas et al. (1976).

\section{RESULTS}

\section{Aerobic expression of the cyf gene in $E$. coli}

Expression of the cyf gene in E. coli TG2(pJRC41) cells produced two forms, $\mathbf{a}$ and $\mathbf{b}$, that were immunoreactive toward the anti-Cyf antiserum (Fig. 2, lanes 2 and 3). Form a migrated with the same mobility as purified $D$.

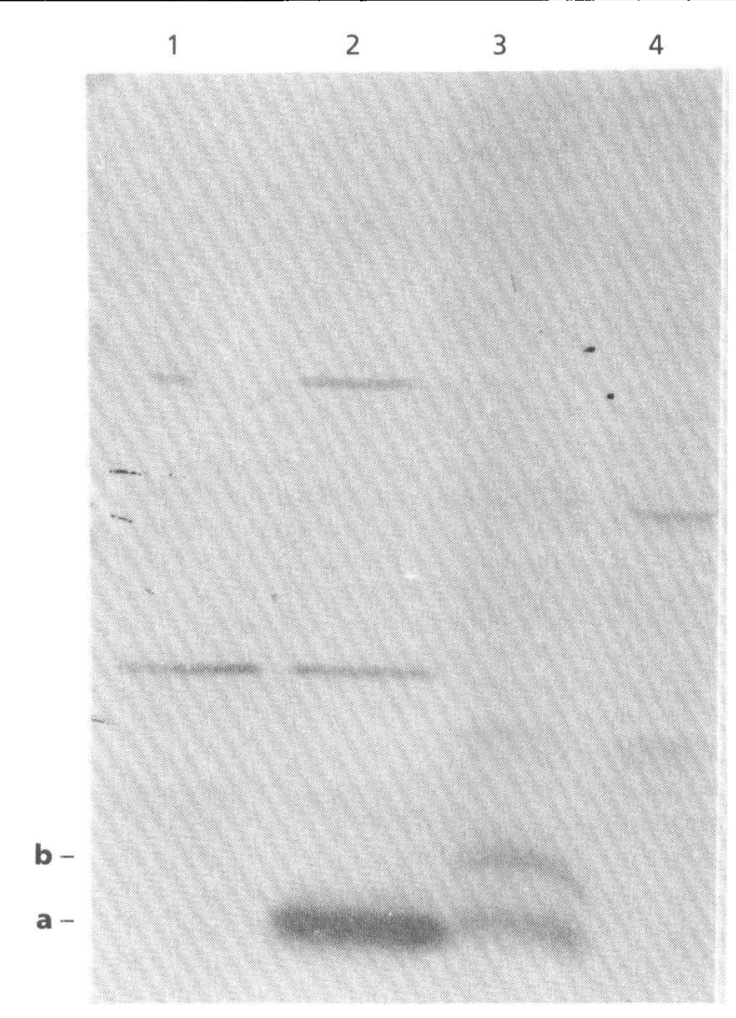

Fig. 2. Expression of the cyf gene in E. coli. Forms $\mathbf{a}$ and $\mathbf{b}$ are explained in Table 2. Samples were analysed by SDS-PAGE using a $7-20 \%$ gradient gel and blotting. The protein blot was incubated with a polyclonal anti-Cyf serum. Lane 1, periplasmic fraction of $E$. coli TG2(pJRD215); lane 2, periplasmic fraction of E. coli TG2(pJRC41); lane 3, membrane/cytoplasmic fraction of E. coli TG2(pJRC41); lane 4, membrane/cytoplasmic fraction of $E$. coli TG2(pJRD215). All cultures were grown in TY medium with $10 \mu \mathrm{g}$ kanamycin $\mathrm{ml}^{-1}$. vulgaris Hildenborough $\operatorname{Cyf}$ (not shown), and was present predominantly in the periplasm. Form b was present in the membrane/cytoplasmic fraction. Neither was expressed in the E. coli TG2(pJRD215) control (Fig. 2, lanes 1 and 4 ) and forms $\mathbf{a}$ and $\mathbf{b}$ thus correspond to the processed and precursor forms of Cyf, respectively (Table 2).

Plasmid pJRC41 contains the cyf gene inserted into vector pJRD215, which does not possess a promoter capable of directing the transcription of any reading frame incorporated into the multiple-cloning site (Davison et al., 1987). Therefore, synthesis of the cytochrome c-553 polypeptide in E. coli TG2(pJRC41) cells indicates that $E$. coli is able to direct transcription of the cyf gene from a $D$. vulgaris Hildenborough promoter element encoded on the insert. The -35 and -10 elements of this promoter have been tentatively identified by comparison to the upstream regions of other D. vulgaris Hildenborough genes (Pollock, 1992).

Both haem labelling and visible spectroscopy indicated that $E$. coli expressed form a as the holoprotein, as discussed in more detail below. This was not expected because $E$. coli was not able to express the holoform of cytochrome $c_{3}$, a tetrahaemic $c$-type cytochrome of the same organism, even though it could accurately process and export the apopolypeptide (Pollock et al., 1989).

Covalent attachment of haem to $c$-type cytochromes can be conveniently demonstrated by labelling cells with 5 amino $\left[4-{ }^{14} \mathrm{C}\right]$ laevulinic acid (von Wachenfeldt \& Hederstedt, 1990a), the first dedicated precursor in haem biosynthesis. Labelling of E. coli TG2(pJRC41) cells under aerobic conditions indicated that Cyf form a was present in the holoform (Fig. 3B, lane 2). Significantly, no other periplasmic c-type cytochromes were detected, which is in agreement with the notion that $E$. coli only expresses $c$-type cytochromes under anaerobic conditions (Bragg \& Hackett, 1983; Kajie \& Anraku, 1986).

Expression of Cyf in the holoform could also be demonstrated by direct spectroscopic analysis of stationary-phase cultures grown aerobically in TY medium, the results of which are summarized in Table 3 . An air-oxidized sample of either $D$. vulgaris Hildenborough cytochrome $c-553$ or the periplasmic fraction obtained from $E$. coli TG2(pJRC41) cells was divided equally between two cuvettes. Sodium dithionite was then added to the sample cuvette. The resulting reduced minus oxidized difference spectra displayed identical absorption maxima and similar values for the ratio $\Delta \varepsilon_{417}: \Delta \varepsilon_{553}$. Spectra obtained for the periplasmic fraction of $E$. coli TG2(pJRD215) cells showed no discernible difference absorbance between $400 \mathrm{~nm}$ and $600 \mathrm{~nm}$ (not shown). These results indicated that the yield of recombinant holocytochrome $c-553$ was approximately $2 \mathrm{mg}$ per litre of E. coli TG2(pJRC41) culture.

The presence of holocytochrome $c-553$ could not be detected either by post-electrophoretic porphyrin- $c$ fluorescence analysis or by staining for haem peroxidase activity using TMBZ as a substrate. 
Table 2. Properties of Cyf and Cyf-Bla fusion proteins synthesized in E. coli transformed with the plasmids indicated in Fig. 1

\begin{tabular}{|c|c|c|c|c|c|}
\hline Form & Haem & Anti-Cyf* & Anti-Bla $\dagger$ & $\begin{array}{l}\text { Mol. } \\
\text { mass } \ddagger\end{array}$ & Remarks \\
\hline a & + & + & - & $9(9)$ & $\begin{array}{l}\text { Periplasmic holoform of Cyf synthesized } \\
\text { in } E \text {. coli TG2(pJRC41); same } \\
\text { migration on SDS-PAGE as Cyf } \\
\text { purified from D. vulgaris } \\
\text { Hildenborough }\end{array}$ \\
\hline $\mathbf{a}^{\prime}$ & + & + & - & 10 & $\begin{array}{l}\text { Periplasmic holoform of Cyf obtained } \\
\text { by proteolytic degradation of forms } \mathbf{c} \\
\text { or } \mathrm{e}\end{array}$ \\
\hline b & ND & + & - & $12(11)$ & $\begin{array}{l}\text { Membrane/cytoplasmic pre-Cyf; } \\
\text { precursor of form a }\end{array}$ \\
\hline c & + & + & + & $45(38)$ & $\begin{array}{l}\text { Periplasmic Cyf-Bla fusion protein } \\
\text { synthesized in E. coli TG2(pDUL } 44) \text {; } \\
\text { as in Fig. 1(B), but without the signal } \\
\text { peptide }\end{array}$ \\
\hline d & - & - & + & 38 & $\begin{array}{l}\text { Periplasmic proteolytic degradation } \\
\text { product of form c }\end{array}$ \\
\hline e & - & + & + & $35(28)$ & $\begin{array}{l}\text { Periplasmic Cyf-Bla' fusion protein } \\
\text { synthesized in E. coli TG2(pDUL45); } \\
\text { as in Fig. 1(B), but without the signal } \\
\text { peptide }\end{array}$ \\
\hline
\end{tabular}

* Reaction of protein with antiserum directed against Cyf.

† Reaction of protein with antiserum directed against Bla.

$\ddagger$ Molecular mass in $\mathrm{kDa}$ determined by SDS-PAGE relative to pre-stained markers as well as Cyf purified from D. vulgaris Hildenborough. Theoretical values are in brackets. Mature $\mathrm{Bla}$ (theoretical molecular mass $29 \mathrm{kDa}$ ) ran as a $36 \mathrm{kDa}$ polypeptide in SDS-PAGE.

ND, Not determined.

Table 3. Visible absorption spectroscopic data for $D$. vulgaris Hildenborough cytochrome c-553 expressed in E. coli

\begin{tabular}{|lll|}
\hline Sample & \multicolumn{2}{c|}{$\begin{array}{c}\text { [Reduced sample-oxidized } \\
\text { sample] }\end{array}$} \\
\cline { 2 - 3 } & \multicolumn{1}{c|}{$\lambda_{\max }(\mathbf{n m})$} & $\Delta \boldsymbol{\varepsilon}_{\mathbf{4 1 7}}: \Delta \boldsymbol{\varepsilon}_{553}$ \\
\hline Cytochrome c-553 & $417,523,553$ & $4 \cdot 4 \pm 0 \cdot 2$ \\
E. coli TG2(p)RC41), aerobic periplasm & $417,523,553$ & $4 \cdot 6 \pm 0 \cdot 2$ \\
E. coli TG2(pDUL44), aerobic periplasm & $417,523,553$ & $4 \cdot 5 \pm 0 \cdot 2$ \\
E. coli TG2(pDUL45), aerobic periplasm & $417,523,553$ & $4 \cdot 2 \pm 0 \cdot 2$ \\
\hline
\end{tabular}

\section{Aerobic expression of the cyf-bla fusions in E. coli}

In order to further delineate the properties of the haem insertion system in E. coli, two vectors expressing Cyf-Bla fusion proteins were constructed (Fig. 1). Plasmid pDUL44 was designed to encode a fusion protein with an $\mathrm{N}$-terminal Cyf and a $\mathrm{C}$-terminal mature Bla domain. Export of this fusion protein is directed by the Cyf signal peptide. Plasmid pDUL45 encoded a similar fusion but with a truncated Bla domain (Fig. 1B, Bla').
The periplasm of stationary-phase cultures of E. coli TG2(pDUL44) was shown to contain three distinct forms: $\mathbf{a}^{\prime}, \mathbf{c}$ and $\mathbf{d}$ (Fig. 3, lane 3; Table 2). Form $\mathbf{c}$ corresponds to the processed fusion polypeptide; it was immunoreactive towards antisera directed against either Bla (Fig. 3A) or Cyf (not shown). Also, incorporation of 5-amino $\left[4-{ }^{14} \mathrm{C}\right]$ laevulinic acid into form c (Fig. 3B) demonstrated the Cyf domain of the fusion to be in the holoform. Form a', which was also in the holoform, is thought to arise from nearly complete degradation of the 
A

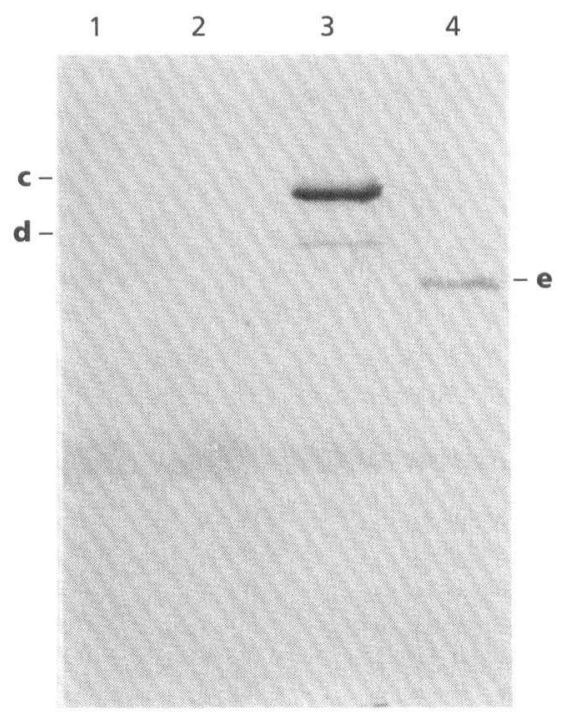

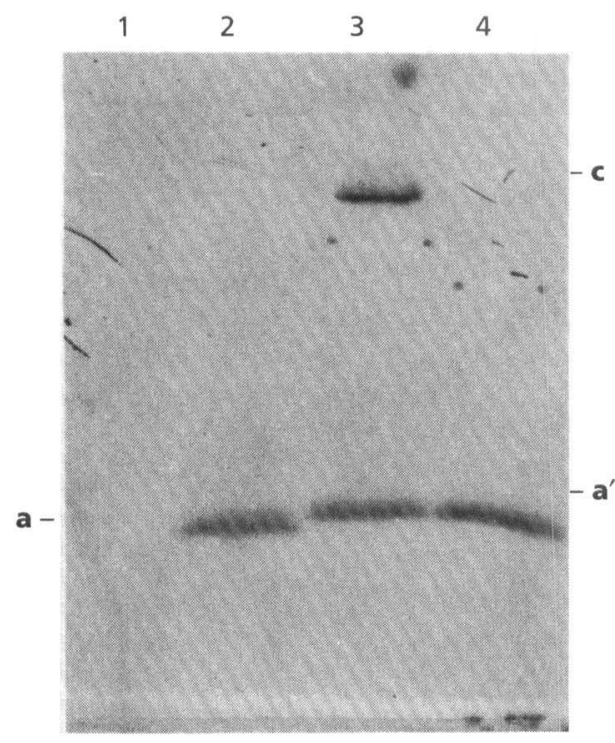

Fig. 3. Incorporation of ${ }^{14} \mathrm{C}$-labelled haem into Cyf and two Cyf-Bla fusion proteins expressed in $E$. coli TG2. The cells were grown overnight in $\mathrm{M} 9$ minimal medium to which 5 -amino[4- $\left.{ }^{14} \mathrm{C}\right]$ laevulinic acid was added to $0.32 \mu \mathrm{Ci} \mathrm{ml}^{-1}$ $\left(11.84 \mathrm{kBq} \mathrm{ml}^{-1}\right)$. Periplasmic fractions were analysed by SDS-PAGE using a 7-20\% gradient gel. Forms $a, a^{\prime}, c, d$ and e are described in Table 2. A, Protein blot incubated with anti-Bla antibodies. Lanes 1-4, E. coli TG2 transformed with pJRD215, pJRC41, pDUL44 or pDUL45, respectively. B, Autoradiogram of the blot in (A).

C-terminal Bla domain of form c because (i) it was immunoreactive to anti-Cyf serum (not shown), but not to anti-Bla serum (Fig. 3A) and (ii) it had only a slightly larger relative molecular mass than $\mathrm{Cyf}$, as judged by SDS-PAGE (Fig. 3B). The haem environment in forms $\left(\mathbf{a}^{\prime}, \mathbf{c}\right)$ was indistinguishable from that in the native cytochrome $c-553$ from $D$. vulgaris Hildenborough by visible absorption spectroscopy (Table 3 ). The third fusion protein, form $\mathbf{d}$, observed in the periplasm of $E$. coli TG2(pDUL44) cells, is also likely to be a degradation product of form $\mathbf{c}$. Form $\mathbf{d}$ may have arisen by partial degradation of the Cyf domain because (i) it demonstrated anti-Bla (Fig. 3A, lane 3) but not anti-Cyf immunoreactivity (not shown) and (ii) its molecular mass, as estimated by SDS-PAGE, was higher than that of mature Bla. Form d did not incorporate haem (Fig. 3B, lane 3).

A simpler, two-component pattern was seen in the periplasmic fraction prepared from E. coli TG2(pDUL45) cells. This fraction contained the mature, full length fusion polypeptide, form e (Table 2), which was immunoreactive to anti-Bla (Fig. $3 \mathrm{~A}$, lane 4 ) and anti-Cyf sera (not shown). However, unlike the corresponding form $\mathbf{c}$ encoded by pDUL44, form $\mathbf{e}$ was only seen in the apoform (Fig. 3B, lane 4). The periplasm from $E$. coli TG2(pDUL45) cells also contained a protein which was identical to form $\mathbf{a}^{\prime}$ by immunoreactivity (not shown), 5amino[4- $\left.{ }^{14} \mathrm{C}\right]$ laevulinic acid incorporation (Fig. 3B, lane 4) and visible absorption spectroscopy (Table 3).

E. coli TG2(pDUL44) cells could grow in the presence of ampicillin indicating that the Bla domain of forms $\mathbf{c}$ and $\mathbf{d}$ was folded and active. E. coli TG2(pDUL45) could not grow in the presence of ampicillin. Form e cannot have $\beta$ - lactamase activity, since the truncated Bla domain lacks the $\beta$-lactam binding site (Herzberg \& Moult, 1987).

\section{Expression of cyf under anaerobic conditions}

Since E. coli expresses its $c$-type cytochromes only under anaerobic conditions, particularly when TMAO is used as the electron acceptor, the possibility of increased holocytochrome $c-553$ expression under these conditions was investigated. Haem incorporation could be demonstrated by ${ }^{14} \mathrm{C}$-labelling (not shown), but spectroscopic analysis using E. coli TG2(pJRD215) controls indicated expression of only $0.03 \mathrm{mg}$ of Cyf per litre of TMAO medium, approximately 70 -fold less than under aerobic conditions.

E. coli TG2(pDUL44) cells grown anaerobically demonstrated ampicillin resistance comparable to cells grown aerobically. This indicated that export of the Cyf-Bla fusion protein to the periplasm was not impaired during anaerobic growth.

\section{DISCUSSION}

In the present study we have shown that holocytochrome $c-553$ from $D$. vulgaris Hildenborough can be readily expressed in the $E$. coli periplasm. This was not expected because we had shown earlier that cytochrome $c_{3}$ from the same organism cannot be expressed in the holoform in $E$. coli under either aerobic or anaerobic growth conditions (Pollock et al., 1989). Also, in the first report of expression of a $c$-type cytochrome in E. coli, expression of holocytochrome $c_{2}$ from Rhodobacter sphaeroides (McEwan $e$ t al., 1989), it was reported that holoprotein synthesis could only be obtained under anoxic conditions, when using 
TMAO as the electron acceptor. These are the same conditions under which $E$. coli expresses its native $c$-type cytochromes (Bragg \& Hackett, 1983). Others have since found that these conditions are not required for heterologous $i$-type cytochrome expression: holoprotein synthesis has been observed in aerobically grown $E$. coli for Bacillus subtilis cytochrome c-550 (von Wachenfeldt \& Hederstedt, 1990b), Hydrogenobacter thermopbilus cytochrome $c-552$ (Sanbongi et al., 1991) and Thiobacillus versutus cytochrome c-550 (Ubbink et al., 1992). The latter was expressed most efficiently under semi-anaerobic conditions, yielding $1-2 \mathrm{mg}$ holocytochrome $1^{-1}$, whereas under strictly aerobic or anaerobic conditions only ca. $0 \cdot 1 \mathrm{mg} \mathrm{l}^{-1}$ was obtained. Our observation of a significant level of expression $\left(2 \mathrm{mg} \mathrm{l}^{-1}\right)$ of holocytochrome c-553 from $D$. vulgaris Hildenborough in $E$. coli under aerobic conditions is inconsistent with the hypothesis that holo-ctype cytochrome expression is absolutely dependent on a host-specific factor, which is expressed in E. coli only under a limited set of conditions (e.g. absence of oxygen, presence of TMAO; McEwan et al., 1989).

In contrast there is evidence that the success or failure of expressing a heterologous gene for a $c$-type cytochrome in $E$. coli in the holoform may depend primarily on the ability of the apoprotein to assume a three-dimensional conformation which is capable of binding haem in an orientation which facilitates covalent bond formation. Evidence for partial folding of apocytochrome $c-550$ from Paracoccus denitrificans was obtained by Page \& Ferguson (1990) by size-exclusion chromatography experiments and indicated that, although somewhat expanded, the apocytochrome retained the dimeric quaternary structure of the holoprotein. The $T$. versutus cytochrome c-550 expressed in $E$. coli as the holoprotein by Ubbink et al. (1992) is highly homologous to the $P$. denitrificans protein. This success may thus originate from formation of a similarly folded apocytochrome in the E. coli periplasm. The results obtained by Sanbongi et al. (1991), who expressed the holoform of cytochrome $c-552$ from the thermophilic Hydrogenobacter thermophilus in the E. coli cytoplasm from a cloned gene lacking the coding region for the $\mathrm{N}$-terminal signal peptide, are at first glance bizarre but can be understood if we assume that the apocytochrome $c-552$ formed in the E. coli cytoplasm is highly structured and, as a result, readily binds haem.

In order to understand the nature of the factors necessary for holocytochrome formation in $E$. coli it is important to note that the in vitro prepared apoform of mitochondrial cytochrome $c$ has no recognizable tertiary (or secondary) structure and cannot react spontaneously with free haem (Sano \& Tanaka, 1964; Stellwagen et al., 1972; Fisher et al., 1973; Cohen et al., 1974). This is in direct contrast to cytochrome $b_{5}$, which adopts a conformation resembling that of a relaxed holoform (Huntley \& Strittmatter, 1972; Moore et al., 1991). Significantly, it has recently been shown that when Asn-57 of cytochrome $b_{5}$, which is in close proximity to the vinyl group at haem position 4 , is replaced by a cysteine an $\alpha$-thioether bond is formed (Barker et al., 1993). This may indicate that a haem-c linkage can occur spontaneously as long as the apopoly- peptide has sufficient secondary and tertiary structure to enable haem binding. A similar $\alpha$-thioether bond can be spontaneously formed between a cysteinyl residue of the phytochrome apopolypeptide and the linear tetrapyrrole prosthetic group phytochromobilin (Li \& Lagarias, 1992). In view of these results we suggest that if a $c$-type cytochrome apopolypeptide, expressed in $E$. coli under aerobic conditions, has a tertiary structure resembling that of the holoprotein its cysteinyl residues may spontaneously form covalent bonds with the haem vinyls. Our suggestion does not preclude the possibility that protein factors may facilitate covalent binding of haem to apocytochromes in other prokaryotes or even in $E$. coli under anaerobic conditions. If proof for the existence of such factors can be obtained then an important question is whether they should be considered to be true enzymes or merely chaperonins with the function to hold the apoprotein in a conformation that allows covalent haem insertion. The factor that aids in covalent haem insertion into mitochondrial cytochrome $c$ has been named cytochrome $c$ haem lyase (Dumont et al., 1987; Drygas et al., 1989), but so far no mechanism for its enzymic action has been put forward, and the possibility that this protein is in fact a cytochrome $c$-chaperonin cannot be ruled out.

It is interesting that, in this work, labelling with 5amino $\left[4-{ }^{14} \mathrm{C}\right]$ laevulinic acid indicated haem incorporation in fusion protein form $\mathbf{c}$, synthesized by $E$. coli TG2(pDUL44) cells, but not in form e, synthesized by $E$. coli TG2(pDUL45) cells. We envisage form $\mathrm{c}$ as consisting initially of a folded apo-Cyf domain connected to a folded Bla domain. The relative position of the two domains is such that spontaneous haem insertion into the apo-Cyf domain is not prevented. This can be rationalized from the three-dimensional structure, which indicates the Cterminal Leu-79 to be distant from the haem (Nakagawa et al., 1990). Proteolysis of form can lead to form $\mathbf{a}^{\prime}$, lacking the Bla domain, or form d, lacking the Cyf domain. Form e consists initially of a folded apo-Cyf domain and part of the Bla polypeptide, which is unlikely to be folded because it is truncated. The presence of this unfolded polypeptide may reduce access of haem to the apo-Cyf domain in the fusion protein. However, its proteolytic degradation yields form $\mathbf{a}^{\prime}$, which readily incorporates haem. These results are not inconsistent with those obtained by von Wachenfeldt \& Hederstedt (1990b) for a CccA-PhoA fusion. These authors observed both the mature fusion polypeptide and a degradation product analogous to our form $\mathbf{a}^{\prime}$ in the apoform, despite the fact that the holocytochrome was formed when the unfused ccc $A$ gene was expressed in aerobic $E$. coli. The method by which the $\mathrm{CccA}-\mathrm{PhoA}$ fusion was generated truncated part of the CccA C-terminus and we suggest that this interfered with folding of the apo-CccA domain in a form competent to bind haem.

In conclusion, it appears that the varying degrees of success obtained during heterologous expression of $c$-type cytochromes in $E$. coli may possibly be explained by differences in folding of the expressed apoproteins. Progress in our understanding of the process of covalent haem insertion may accelerate upon more extensive 
biophysical investigation of the conformation of these apoproteins, and upon devising strategies for finding genes, whose products modulate this conformation.

\section{ACKNOWLEDGEMENTS}

The authors would like to thank Kuldip Hayer and Joe Vipond for plasmid constructions, Dr Mireille Bruschi for the gift of puritied D. vilgaris Hildenborough cytochrome $6-553$ and $\mathrm{Dr}$ A. G. Mauk for the communication of unpublished data. This work was supported by a graduate scholarship to W. B.R. P. from the Nberta Heritage Foundation for Medical Research and by a grant from the Natural Sciences and Inginecring Rescarch Council of Canada to G.V.

\section{REFERENCES}

Barker, P. D., Ferrer, J. C., Mylrajan, M., Loehr, T. M., Feng, R., Konishi, Y., Funk, W. D., MacGillivray, R. T. A. \& Mauk, A. G. (1993). Transmutation of a heme protein. Proc Nall Acad Sci LIS.4 90, 6512-6516

Beckman, D. L., Trawick, D. R. \& Kranz, R. G. (1992). Bacterial cytochromes $i$ biogenesis. Cenes \& Dev 6, 268-283.

Biel, S. W. \& Biel, A. J. (1990). Isolation of a Rhodobacter capsulatrs mutant that lacks e-type cytochromes and excretes porphyrins. $J$ Basteriol 172, 13211326 .

Bragg, P. D. \& Hackett, N. E. (1983). Cytochromes of the trimethylamine- $N$-oxide anacrobic respiratory pathway of Escher ihia coli. Biochim Biopby. Acta 725, 168177.

Cannac, V., Caffrey, M. S., Voordouw, G. \& Cusanovich, M. A. (1991). Fixpression of the gene encoding cytochrome $c_{3}$ from the sulfate-reducing bacterium Desulforibrio imlgaris in the purple photosynthetic bacterium Khodohacter sphaeroides. Arch Bioclsen Biophys 286, 629632

Cohen, J. S., Fisher, W. R. \& Schechter, A. N. (1974). Spectroscopic studies on the conformation of cytochrome $c$ and apocytochromc $c$ J Bin/ Chem 249, 1113-1118.

Davison, J., Heusterpreute, M., Chevalier, N., Vinh. H.T. \& Brunel, F. (1987). Vectors with restriction site banks. V. pJRD215, a wide-host-range cosmid vector with multiple cloning sites. Gent 51,275280 .

Drygas, M. E., Lambowitz، A. M. \& Nargang, F. E. (1989). C.loning and analysis of the Newrospora crassa genc for cytochrome $c$ heme liase. I Biol Chem 264, 1789? 17906.

Dumont, M. E., Ernst J. F., Hampsey, D. M. \& Sherman, F. (1987). Identification and sequence of the gene encoding cytochrome? heme lyase in the yeast Saccharomyces cerevisiat. $2 M B O O$ J 6, 235241.

Fisher, W. R., Taniuchi, H. \& Anfinsen, C. B. (1973). ()n the role of heme in the formation of the structure of cytochrome $\mathrm{c}$.J Binl Chem 248,31883195

Grisshammer, R., Oeckel, C. \& Michel, H. (1991). Expression in tisclierichia coli of $t$-type cytuchrome genes from Rhodopseudomonas viridis. Biochim Biophys . Acta 1088, $183-190$.

Herzberg, O. \& Moult, J. (1987). Bacterial resistance to $\beta$-lactam antibiotics: crystal structure of $\beta$-lactamase from Stapbylococcus auress $\mathrm{P}(\mathrm{C} 1$ at $2 \cdot 5 \mathrm{~A}$ resolution. Science 236, (9)4 701.

Huntley, T. E. \& Strittmatter, P. (1972). The effect of heme binding on the tryptophan residue and the protein conformation of cytochrome $b_{3}$. J Biol Ctem 247, 46414647.

Kajie, S. \& Anraku, Y. (1986). Purification of a hexaheme cytochrome $\epsilon_{552}$ from Escherichia coli $\mathrm{K} 12$ and its properties as a nitrite reductase. Eur / Biocbem 154, 45 ? 463.
Laemmli, U. K. (1970). Cleavage of structural proteins during the assembly of the head of bacteriophage T4. Nature 227, $6806(8.5$.

Li, L. \& Lagarias، J. C. (1992). ['hytochrome assembly: defining chromophore structural requirements for covalent attachment and photoreversibility. J Biol Chem 267, 19214419210.

Marion, D. \& Guerlesquin, F. (1992). Sequential V.MR resonance assignment and sccondary structure of ferrocytochrome $c_{i j 3}$ from Desulfouibrio aulgaris Hildenborough. Biacbemistry 31, 8171-8179.

McEwan, A. G., Kaplan, S. \& Donohue, T. J. (1989). Sỵthesis of Rhodobucter sphaeroides cytochrome $c_{2}$ in Lischerichia cold. Fitills Microbiol Lett 59, 253258.

Messing, J. (1983). Leu M13 vectors tor cloning. Methods Linzymol $101,2078$.

Miller, J. H. (1972). lixperiments in Molecular Genetics, p. 431. Cold Spring Harbor, NY: Cold Spring Harbor I aboratory.

Moore, C. D., Al-Misky, O. N. \& Lecomte, J. T. J. (1991). Similarities in structure between holocytochrome $b_{5}$ and apocytochrome $b_{5}$ : NMR studies of the histidine residues. Bios bemistry 30, $835: 836.5$.

Nakagawa, A., Higuchi, Y., Yasuoka, N., Katsube, Y. \& Yagi, T. (1990). S-class cytochromes $c$ have a varicty of folding parterns: structute of citochrome $c-553$ from Desulforibrio rulgaris determined by the multi-wavelength anomalous dispersion method. I Bioibem 108, 701703 .

Nivière, V., Wong, S.-L. \& Voordouw, G. (1992). Site-directed mutagenesis of the hydrogenase signal pepride consensus box prevents export of a $\beta$-lactamase fusion protcin. J Gen Microbin/ 138. 21732183.

Page, M. D. \& Ferguson, S. J. (1990). A pu furms of cytochronc $i_{5 j 0}$ and cytochrome $d_{1}$ are translocated to the periplasm of Paracoicus denitrificans in the absence of hacm incorporation caused by either mutation or inhibition of hacm synthesis. Mo/ Microbiol 4, 1181-1192.

Pollock, W. B. R., Chemerika, P. J., Forrest, M. E., Beatty, J. T. \& Voordouw, G. (1989). Fxpression of the gene encoding cytochrome $c_{3}$ from Desulforibrio malgaris (Hildcnborough) in Fischericbia coli: export and processing of the apoprotcin. I Gen Microbiol 135, 2319-2328.

Pollock, W. B. R., Loutfi, M., Bruschi, M., Rapp-Giles, B. J., Wall, J. D. \& Voordouw, G. (1991). Cloning, sequcncing, and expression of the gene encoding the high-molecular-wight cytochrome $c$ from Desulforibrio vulgaris Hildenborough. / Bacteriol 173, 220228.

Pollock, W. B. R. (1992). Molecular biology of c-type cytoctromes fromt the sulfate-reducing bacterium Desulfowibrio talgaris Hildenborougts. [3h thesis, Lniversity of Calgary, Alberta, Canada.

Postgate, J. R. (1984). The Sulphate-reducing Bacteria, 2nd edn. Cambridge: Cambridge Lniversity Press.

Ramseier, T. M., Winteler, H. V. \& Hennecke, H. (1991). Discovery and sequence analysis of bacterial genes involved in the biogenesis of c-type cytochromes. $J \mathrm{Bin} / \mathrm{Cbem} 266,77937803$.

Sambrook, J., Fritsch, E. F. \& Maniatis, T. (1989). Holecular Cloning: a Laborafory Manual, 2nd adn. Cold Spring Harbor, NY': Cold Spring Harbor Laboratory.

Sanbongi, Y., Igarashi, Y. \& Kodama, T. (1989). Thermostability of cytochrome $c 552$ from the thermophilic hydrogen-oxidizing bacterium Hydrogenthacter thermoplilus. Biochemistry 28, 95749578.

Sanbongi, Y., Yang, J. H., Igarashi, Y. \& Kodama, T. (1991). Cloning, nucleotide sequence and expression of the cytochrome $i$ 552 gene from lydrogenobacter thermophilus. I:ur J Biachem 198, $i 12$.

Sano, S. \& Tanaka, K. (1964). Recombination of protoporphyrinogen with cytochrome 6 apoprotein. I Biol Cbem 239, 3109-3118. 
Self, S. J., Hunter, C. N. \& Leatherbarrow, R. J. (1990). Molecular cloning, sequencing and expression of cytochrome $c_{2}$ from Rhodospirillum rubrum. Biochem J 265, 599-604.

Stellwagen, E., Rysavy, R. \& Babul, G. (1972). The conformation of horse heart apocytochrome $c$. J Biol Chem 247, 8074-8077.

Thomas, P. E., Ryan, D. \& Levin, W. (1976). An improved staining procedure for the detection of the peroxidase activity of cytochrome P-450 on sodium dodecyl sulfate polyacrylamide gels. Anal Biochem 75, 168-176.

Ubbink, M., van Beeumen, J. \& Canters, G. W. (1992). Cytochrome $c_{550}$ from Thiobacillus versutus: cloning, expression in Escherichia coli, and purification of the heterologous holoprotein. J Bacteriol 174, 3707-3714.

Van Rooijen, G. J. H., Bruschi, M. \& Voordouw, G. (1989). Cloning and sequencing of the gene encoding cytochrome $c_{553}$ from Desulfovibrio vulgaris Hildenborough. J Bacteriol 171, 3575--3578.

Vieira, J. \& Messing, J. (1982). The pUC plasmids, an M13mp7derived system for insertion mutagenesis and sequencing with synthetic universal primers. Gene 19, 259-268.

Von Wachenfeldt, C. \& Hederstedt, L. (1990a). Bacillus subtilis $13-$ kilodalton cytochrome $c-550$ encoded by $c c c$ A consists of a membrane-anchor and a heme-domain. $J$ Biol Chem 265, 13939-13948.

Von Wachenfeldt, C. \& Hederstedt, L. (1990b). Bacillus subtilis holo-cytochrome $c$-550 can be synthesized in aerobic Eschericbia coli. FEBS Lett 270, 147-151.

Voordouw, G., Strang, J. D. \& Wilson, F. R. (1989). Organization of the genes encoding [Fe] hydrogenase in Desulfovibrio vulgaris subsp. oxamicus Monticello. $J$ Bacteriol 171, 3881-3889.

Weimar, P. J., van Kavelaar, M. J., Michel, C. B. \& Ng, T. K. (1988). Effect of phosphate on the corrosion of carbon steel and on the composition of corrosion products in two-stage continuous cultures of Desulfovibrio desulfuricans. Appl Environ Microbiol 54, 386-396.

Yanisch-Perron, C., Vieira, J. \& Messing, J. (1985). Improved M13 phage cloning vectors and host strains: nucleotide sequences of the M13mp18 and pUC19 vectors. Gene 33, 103-119.

Received 22 July 1993; revised 26 October 1993; accepted 11 November 1993. 